\title{
MEMPERSIAPKAN LULUSAN SARJANA MENJADI PENCIPTA LAPANGAN PEKERJAAN
}

\author{
Kuspuji Catur Bagus Wicaksono \\ Jurusan Manajemen, Fakultas Ekonomi dan Bisnis, Bina Nusantara University \\ Jl. K.H. Syahdan No. 9, Kemanggisan, Palmerah, Jakarta Barat 11480 \\ gundamocil12@yahoo.com
}

\begin{abstract}
The amount of graduates and the availability of jobs are unbalanced, therefore unemployment is generalized; not only for uneducated but also those educated ones. This is supporting educational institutions to provide entrepreneurship subject for students to prepare themselves when they have no job and unemployment for the consequences. Entrpreneurial education is not about theory but also field practice that involves every parts such as educational institutions, small-scale and major business, and also government. Education that moves accordingly with the development and field practice for students to be prepared for their graduation, whether or not being an entrepreneur.
\end{abstract}

Keywords: entrepreneur, entrepreneur characteristics, entrepreneur education

\begin{abstract}
ABSTRAK
Tingkat kelulusan sarjana yang tidak seimbang dengan lapangan pekerjaan tersedia, sehingga pengangguran tidak hanya yang tidak mempunyai pendidikan dan juga mempunyai sarjana. Hal ini mendorong institut pendidikan untuk melakukan tindakan dengan memberikan pendidikan entrepreneurship bagi mahasiswa untuk mempersiapkan apabila tidak mendapatkan pekerjaan dan menganggur akibatnya. Pendidikan entrepreneur yang diberikan tidak hanya teori saja akan tetapi juga praktek di lapangan dengan melibatkan semua pihak yaitu institut pendidikan, pengusaha skala kecil, menengah dan besar, begitu juga pemerintah. Pendidikan yang sesuai dengan perkembangan dan praktek dilapangan dengan tujuan agar mahasiswa siap menjelang kelulusannya untuk menentukan langkahnya menjadi entrepreneur atau tidak.
\end{abstract}

Kata kunci: entrepreneur, karakter entrepreneur, pendidikan entrepreneur 


\section{PENDAHULUAN}

Jumlah angkatan kerja yang bertambah setiap tahunnya tidak seimbang dengan jumlah lapangan pekerjaan tersedia dan mampu menampungnya. Hal ini menciptakan sarjana pengangguran dimana-mana, walaupun mereka mempunyai gelar sarjana pendidikan tetapi tidak menjamin untuk mereka mendapatkan lapangan pekerjaan. Maka dari itu diperlukan persiapan membekali para lulusan sarjana yang apabila setelah lulus tidak mendapatkan pekerjaan yang diinginkan. Salah satunya selain terus menerus mencari lapangan pekerjaan atau mencoba berusaha mandiri dengan menjadi pengusaha atau entrepreneur. Salah satu sumbangsih bagi lulusan sarjana yang tidak mendapatkan lapangan pekerjaan adalah juga menciptakan lapangan pekerjaan, sehingga para lulusan sarjana dapat mempraktekkan atau mengimplementasikan apa yang telah diperoleh di perkuliahan dalam lapangan. Dengan terciptanya sebuah lapangan pekerjaan baru oleh para lulusan sarjana yang menjadi pengusaha atau entrepreneur, walaupun usahanya dalam skala kecil atau menengah, mereka mempunyai potensi untuk jangka panjang lebih baik dibandingkan mereka yang langsung memulai besar akan tetapi tidak bisa menjalaninya.

Salah satu tokoh entrepreneur dalam negeri Bob Sadino dalam Al-Firdaus (2010) mengungkapkan keprihatinan melihat sistem pendidikan yang berjalan telah dikondisikan untuk mengajarkan tahu dan tidak mempedulikan untuk bisa. Sehingga bisa dikatakan bahwa pendidikan yang ada sekarang adalah bukan pendidikan akan tetapi pengajaran. Pelaku pendidik hanya memindahkan pengetahuan atau teori kepada mahasiswa, tidak mengikutkan prakteknya. Oleh karena itu, pendidikan terutama entrepreneurship harus didasarkan pada teori yang akan dipraktekkan. Pelaku pendidik tidak hanya sekedar memberi tahu, akan tetapi harus memberikan contoh untuk melakukannya. Mendidiklah dengan keteladanan, tidak hanya lewat mulut atau verbal saja seperti yang dipraktekkan di sekolah kejuruan.

Ada ungkapan yang menarik dari sebuah film non fiksi, dimana tokoh utamanya sedang berlatih dengan gurunya. Sang tokoh utama diperintahkan untuk memindahkan suatu benda yang lebih besar daripada dirinya sendiri dengan menggunakan kekuatan tenaga dalam, akan tetapi karena tokoh utama terlanjur tertanam di benak pikirannya bahwa dia tidak mungkin bisa melakukan hal tersebut sehingga timbul rasa keterpaksaan untuk itu. Tokoh utama dengan berat hati melakukannya sembari berkata akan saya coba, lalu dipotong bicaranya langsung oleh gurunya dengan perkataan "lakukan atau tidak lakukan, tidak ada yang namanya coba-coba”. Kata itu memberikan dorongan ke tokoh utama untuk melakukannya bukan hanya untuk mencoba-coba, beda disitu. Seperti halnya apabila seseorang individu ingin membuka usaha sendiri, individu tersebut harus terlebih dahulu menanamkan di dalam dirinya lakukan dengan sungguh-sungguh dan jangan hanya mencoba-coba. Karena hasil yang diraihnya akan berbeda apabila dilakukan dengan sungguh-sungguh dibandingkan apabila hanya mencoba-coba. Karena dalam membuka usaha, apabila melakukannya untuk coba-coba saja maka bisa dipastikan bahwa walaupun usahanya berjalan akan tetapi tidak akan mengalami kemajuan yang signifikan. Kenapa bisa terjadi hal seperti itu? Disebabkan karena tidak melakukannya dengan kesungguhan dan keinginan untuk meraih sesuatu di dalam dirinya, padahal dalam membuka dan menjalani suatu usaha dibutuhkan kesungguh-sungguhan dari individu yang akan melakukannya.

Cerita ini berkaitan dengan mengapa banyak lulusan sarjana tidak mau mengambil kesemptan yang tersedia untuk mencoba menjadi entrepreneur. Disebabkan tidak mendapatkan pendidikan yang cukup untuk mendalami dan terjun ke dunia entrepreneurship. Selain itu juga penerapannya di baik di lapangan dan institut yang kurang dan tidak memadai menyebabkan keinginan mahasiswa untuk terjun ke entrepreneur mengalami kendala. 


\section{PEMBAHASAN}

Semakin banyak sarjana yang dihasilkan oleh setiap universitas setiap tahun dengan berbagai macam latar belakang dan pendidikan yang tersedia. Akan tetapi hal ini tidak sejalan dengan perkembangan jumlah lapangan pekerjaan yang tersedia untuk menyerap para lulusan sarjana. Apalagi dengan semakin berkembangnya tuntutan yang diperlukan dalam setiap jenis pekerjaan yang tersedia telah memberikan dampak semakin banyak sarjana yang tidak terserap. Begitu juga dengan lapangan pekerjaan tidak tersedia dalam jumlah yang cukup dikarenakan banyak perusahaan besar berjatuhan oleh karena krisis perekonomian berkepanjangan.

Institut pendidikan mempunyai kewajiban untuk memberikan pendidikan dan menanamkan harapan kepada masyarakat bahwa setiap anaknya yang diterima akan mendapatkan masa depan cerah dengan menjadi pekerja. Walaupun terkesan bagus akan tetapi sang anak tidak hanya bersaing di dalam pendidikannya dengan pelajar yang lain, juga saat kelulusannya bersaing pula dengan lulusan lainnya dalam mencari lapangan pekerjaan yang sesuai latar belakang pendidikan yang dia dapat. Dan itu belum bersaing dengan lulusan dari institut pendidikan baik dalam maupun luar negeri.

Sehingga lulusan sarjana tidak hanya dibekali dengan gelar yang didapatnya akan tetapi juga diperlukan kemampuan lain, salah satunya adalah kemampuan berwirausaha. Padahal pembelajaran entrepreneurship bukan hanya menciptakan lulusan sarjana yang dapat bebas dari kemiskinan dan kebodohan, akan tetapi juga menjadi kekuatan yang mendorong kemajuan perekonomian yang merata dan sejahtera. Perlunya institut pendidikan untuk memberikan pendidikan entrepreneurship kepada mahasiswa untuk menanamkan dan menumbuhkan semangat entrepreneurship, sehingga mereka bisa menjadi pendorong untuk perekonomian dengan menciptakan jenis usaha baru atau perkembangan dari yang sudah ada, menciptakan lapangan pekerjaan, dengan memperbaiki kesejahteraaan dan akhirnya mendorong perekonomian.

\section{Landasan Teori}

Penanaman kemampuan entrepreneurship perlu dilakukan karena dilatar belakangi dengan semakin banyak lulusan sarjana yang bersaing dalam mencari lapangan pekerjaan, sehingga diperlukan adanya hal ini untuk membantu mereka yang tidak berkeinginan bekerja di sebuah perusahaan atau yang tidak mendapatkan pekerjaan, akan tetapi masih mempunyai alternatif. Persiapan ini salah satunya dimulai dari sekolah atau institut pendidikan, tempat mereka menimba ilmu, di mana mereka dipersiapkan baik secara ilmu dan juga praktek. Tentunya hal ini membutuhkan kurikulum yang matang, terencana dan efektif. Dalam hal ini peran pemerintah amat mendukung dalam menyediakan berbagai sarana dan fasilitas yang berkesinambungan. Untuk membentuk entrepreneur maka kita melihat terlebih dahulu teori-teori yang mengenai proses pembentukan entrepreneur.

\section{Teori Life Path Change}

Teori yang menurut Shapero \& Sokol dalam Rambat Lupiyoadi (2004). Teori yang menyatakan bahwa tidak semua entrepreneur lahir dan berkembang mengikuti jalur yang sistematis dan terencana. Banyak orang yang menjadi entrepreneur justru tidak melalui proses yang direncanakan. Antara lain disebabkan oleh: (1) negative displacement, seeorang bisa saja menjadi entrepreneur gara-gara dipecat dari tempatnya bekerja, tertekan, terhina atau mengalami kebosanan selama bekerja, dipaksa atau terpaksa pindah dari daerah asal, atau bisa juga karena sudah memasuki usia pension atau cerai perkawinan dan sejenisnya; (2) being between things, orang-orang yang baru keluar dari ketentaraan, sekolah atau penjara. Kadangkala merasa seperti memasuki dunia baru yang belum mereka mengerti dan kuasai. Keadaan ini membuat mereka seakan berada di tengah-tengah dari 
dua dunia yang berbeda, namun mereka tetap harus berjuang menjaga kelangsungan hidupnya; (3) having positive pull, terdapat juga orang-orang yang mendapat dukungan membuka usaha dari mitra kerja, investor, pelanggan atau mentor. Dukungan memudahkan mereka dalam mengantisipasipeluang usaha, selain itu juga menciptakan rasa aman dari risiko usaha.

\section{Teori Goal Directed Behaviour}

Seseorang dapat saja menjadi entrepreneur karena termotivasi untuk mencapai tujuan tertentu. Teori ini menggambarkan bagaimana seseorang tergerak menjadi entrepreneur, motivasinya dapat terlihat langkah-langkahnya dalam mencapai tujuan. Diawali dari adanya dorongan need, kemudian goal directed behavior, sehingga tercapai tujuan. Sedangkan need itu sendiri dari skema muncul karena adanya defisit dan ketidak seimbangan tertentu pada diri individu yang bersangkutan dalam hal ini entrepreneur.

\section{Teori Pengambilan Keputusan}

Sebelum mengambil keputusan terjun dalam dunia entrepreneur, seseorang terlebih dahulu melakukan pertimbangan-pertimbangan. Pengambilan keputusan tersebut tidaklah selalu mudah, bahkan dapat menimbulkan konflik dengan dirinya sendiri atau orang lain, dengan keluarga. Teori ini sendiri dipengaruhi oleh beberapa faktor, yaitu: faktor-faktor yang berasal dari situasi lingkungan keputusan itu sendiri serta faktor-faktor yang berasal dari dalam diri si pengambil keputusan sendiri.

\section{Teori Outcome-Expectancy}

Bandura (1986) menyatakan bahwa teori ini bukan suatu perilaku tetapi keyakinan tentang konsekuensi yang diterima setelah seseorang melakukan suatu tindakan tertentu. Menurut Bandura, "judgement about likely consequences of specific behaviours in particulat situations" (p. 82). Dari definisi tersebut, outcome-expectancy dapat diartikan sebagai keyakinan seseorang mengenai hasil yang akan diperolehnya jika ia melaksanakan suatu perilaku tertentu, yaitu perilaku yang menunjukkan keberhasilan. Berbagai jenis insentif sebagai imbalan kerja yang diharapkan individu dan setiap jenis memeiliki kekhasan sendiri. Jenis insentif tersebut adalah: (1) insentif primer, imbalan yang berhubungan dengan kebutuhan fisiologis kita seperti makan, minum, kontak fisik dan sebagainya. Insentif diperkuat nilainya jika seseorang dalam keadaan sangat kekurangan; (2) insentif sensoris, imbalan dimana beberapa kegiatan manusia ditujukan untuk memperoleh umpan balik sensoris yang terdapat di lingkungannya; (3) insentif sosial, manusia akan melakukan sesuatu untuk mendapatkan penghargaan dan penerimaan dari lingkungan sosialnya. Penerimaan atau penolakan dari sebuah lingkungan social akan lebih berfungsi secara efektif sebagai imbalan atau hukuman daripada reaksi yang berasal dari satu individu; (4) insentif yang berupa token ekonomi, imbalan yang berkaitan dengan pemenuhan kebutuhan ekonomi seperti upah, kenaikan pangkat, penambahan tunjangan, dan lain-lain; (5) insentif yang berupa aktivitas, imbalan yang akan mempengaruhi perilaku dengan cara memuaskan atau mengurangi dorongan fisiologis; (6) insentif status dan pengaruh, imbalan berupa status dan pengaruh yang dimiliki individu dalam lingkungan social memberikan kesempatan kepadanya untuk mengontrol perilaku orang lain, baik melalui symbol atau secara nyata. Dengan kedudukan yang tinggi dalam masyarakat, mereka dapat menikmati imbalan materi, penghargaan social, kepatuah, dan lain-lain. Keuntungan yang khas ini membawa individu berusaha keras untuk mencapai posisi yang memberikan kekuasaan; (7) insentif berupa terpenuhinya standar internal, berasal dari tingkat kepuasan diri yang diperoleh individu dari pekerjaannya. Insentif bukan berasal dari hal di luar diri, tetapi berasal dari dalam diri seseorang. Reaksi diri yang berupa rasa puas dan senang merupakan salah satu bentuk imbalan internal yang ingin diperoleh seseorang dari pekerjaannya.

Penanaman yang harus dilakukan kepada para mahasiswa adalah mengetahui sembilan karakter dari para entrepreneneur menurut Sukardi (dalam Rambat Lupiyoadi, 2004), yaitu (1) sifat 
instrumental, menunjukkan bahwa entrepreneur dalam berbagai situasi selalu memanfaatkan segala seusatu yang ada di lingkungannya untuk mencapai tujuan pribadi dalam berusaha. Selalu mencari segala sesuatu yang dapat dimanfaatkan untuk memperbaiki kinerjanya; (2) sifat prestatif, menunjukkan bahwa entrepreneur dalam berbagai situasi selalu tampil lebih baik, efektif dibandingkan dengan hasil yang dicapai sebelumnya. Selalu berbuat lebih baik, tidak pernah puas dengan hasil yang dicapai sekarang, dan selalu membuat target yang lebih baik dan lebih tinggi dari sebelumnya; (3) sifat keluwesan bergaul, menunjukkan bahwa entrepreneur selalu berusaha untuk cepat menyesuaikan diri dalam berbagai situasi hubungan antar manusia. Selalu aktif bergaul, membina kenalan-kenalannya dan mencari kenalan baru serta berusaha untuk dapat terlibat dengan mereka yang ditemui dalam kegiatan sehari-hari; (4) sifat kerja keras, menunjukkan bahwa entrepreneur selalu terlibat dalam situasi kerja, tidak mudah menyerah sebelum pekerjaan selesai. Mengutamakan kerja dan mengisi waktu yang ada dengan perbuatan yang nyata untuk mecapai tujuan. Keterlibatannya dalam kerja tidak semata-mata demi hasil akhir apakah itu kegagalan atau keberhasilan tetapi yang lebih penting dia tidak mau berpangku tangan saja dan lebih nyaman bila terlibat dalam pekerjaan nyata; (5) sifat keyakinan diri, menunjukkan entrepreneur selalu percaya pada kemampuan diri, tidak ragu-ragu dalam bertindak bahkan memiliki kecenderungan untuk melibatkan diri secara langsung dalam berbagai situasi; (6) sifat pengambilan resiko, menunjukkan bahwa entrepreneur selalu memperhitungkan keberhasilan dan kegagalan dalam melaksanakan kegiatan dalam mencapai tujuan berusaha; (7) sifat swa-kendali, menunjukkan bahwa dalam menghadapi berbagai situasi selalu mengacu pada kekuatan dan kelemahan pribadi, batas-batas kemampuan dalam berusaha; (8) sifat inovatif, menunjukkan bahwa entrepreneur selalu mendekati berbagai masalah dalam berusaha dengan cara-cara baru yang lebih bermanfaat. Terbuka untuk gagasan, pandangan, dan penemuan baru yang dapat dimanfaatkan untuk meningkatkan kinerjanya; (9) sifat kemandirian, menunjukkan bahwa entrepreneur selalu mengembalikan perbuatannya sebagai tanggung jawab pribadi. Keberhasilan dan kegagalan merupakan konsekuensi pribadi entrepreneur.

Selain itu sifat entrepreneur adalah hasil proses belajar yang diperkuat oleh Sarasson (Rambat Lupiyoadi, 2004) yaitu: (1) bila seorang individu dewasa sebelumnya yakin bahwa dia dapat dan mampu mengadopsi cara-cara tingkah laku baru khususnya untuk mengubah kepribadiannya, maka kemungkinan keberhasilannya akan lebih besar; (2) bila individu dewasa mempersepsikan bahwa perubahan yang harus dia lakukan seusai dengan tuntutan yang wajar dari tujuan yang ia capai, perubahan akan mudah terjadi; (3) bila individu dewasa dapat secara lebih jelas mendapatkan gambaran langkah-langkah yang harus dia lakukan untuk mengubah pribadinya, perubahan akan mudah terjadi; (4) makin mengalami secara nyata seorang individu dewasa bahwa perubahan yang ia lakukan memang berkaitan langsung dengan pencapaian tujuan, maka makin mudah dia untuk mengubah diri; (5) makin mendapatkan pengalaman nyata seorang individu dewasa bahwa perubahan pribadi membawa keberhasilan, makin mudah perubahan terjadi. Perubahan pribadi makin terwujud apabila lingkungan si individu dewasa menunjang perubahan tadi.

Teori ini membuktikan bahwa siapapun dapat menjadi seorang wirausah kalau ia mau dan tekun. Ini juga membuktikan bahwa tidak ada hambatan yang sifatnya keturunan bagi seseorang untuk menjadi entrepreneur. Bagi institut pendidikan jangan hanya membekali dengan pengetahuan umum yang didapat dari perkuliahan, tanpa memperkenalkan tantangan hidup di kemudian hari dimana kelulusan tidak selalu menjamin kenyamanan dalam mencari pekerjaan. Apalagi bagi mereka yang kurang beruntung, tidak dapat menikmati jenjang pendidikan karena tidak punya modal untuk memasukkan anaknya kedalam institut tersebut. Sehingga sangat diperlukan dan harus dilaksanakannya pendidikan entrepreneurship di dalam sekolah.

Maka, diperlukan petunjuk dalam melaksanakan pendidikan entrepreneurship di institut pendidikan. Seperti sembilan gagasan Asmani (2011), yaitu: (1) adanya pendidikan ketrampilan hidup, pembekalan kemampuan mempertahankan eksistensi, jati diri dan aktualisasi. Dengan tujuan agar mampu bertahan dimanapun berada menggunakan kemampuan yang dimilikinya. Berhubungan dengan aspek sosial, intelektual dan spiritual, keahlian bergaul, kecepatan berpikir dan memotivasi 
dirinnya serta berpegang pada agamanya dengan kuat. (2) Memperbanyak praktik dan teori, memberikan tidak hanya di kelas akan tetapi juga di luar kelas dengan langsung melibatkan di lapangan. Bentuk pembelajaran yang interaktif dan aplikatif baik dalam berbagai bentuk contoh usaha seperti berjualan di sekolah, berternak ikan di tambak atau mengembangbiakkan ayam dan hewan ternak lainnya. Ini baru contoh kecil yang bisa dilakukan dengan pendidikan dan pengawasan tidak terlalu berat. Dengan tujuan agar para lulusan semakin mengerti cara menguasai satu kemampuan yang dimilikinya dan juga dikembangkan pasca lulus dari sekolah. (3) Mendirikan pusat pendidikan dan pelatihan yang mengikuti berbagai perkembangan wawasan, wacana, pemikiran dan gagasan tentang entrepreneurship dari pelosok dunia. Lembaga yang dibawahi institut pendidikan ini menjalankan tugasnya untuk melakukan penelitian, pengembangan dan percobaan yang tidak terusmenerus, dengan tujuan agar ilmu yang dihasilkan benar-benar terbukti, terbaru dan efektif.

(4) Mengembangkan metodologi pengajaran yang bisa langsung diterapkan di lapangan, motivatif, kreatif dan inspiratif. Mengembangkan cara pembelajaran yang akan menggerakkan semangat pelajar dalam mempelajari dan mempraktekkan entrepreneurship. (5) Tiga ranah pendidikan dan tingkat penugasan , meliputi pengetahuan, ketrampilan dan sikap. Dan setiap ranah tersebut mempunyai beberapa tingkat atau tahap kemampuan yang harus dicapai. Untuk tiga ranah pendidikan serta tingkat atau tahap kemampuan tersebut diperlukan model pembelajaran seperti kuliah, tutorial, diskusi kelompok, seminar, praktikum, simulasi, kerja lapangan dan lain sebagainya disesuaikan dengan masing-masing peminatan. (6) Strategi atau inovasi pembelajaran itu sendiri, berfokus pada bagaimana proses pembelajaran di sekolah yang memadai dan saling berinteraksi tanpa ada lagi status quo terlibat didalamnya. Semua sama-sama memulai dari bawah, sama-sama belajar, sama-sama membantu dan sama-sama membangun atau mengembangkan.

(7) Peran pengelola jurusan, yang dimana pengelola ikut terjun dalam merancang, memonitor serta mengevaluasi dengan penuh tanggung jawab dan konsisten. Dan dengan prasyarat perubahan meliputi visi yang berani, pendekatan yang sistematik, maksud dan arah perubahan yang jelas, metode pembelajaran yang spesifik dan kepemimpinan yang efektif. Salah satu upaya untuk mengurangi tingkat pengangguran yang bersumber pada jumlah lulusan pendidikan yang semakin meningkat dan kesempatan kerja yang terbatas, adalah menyiapkan mahasiswa untuk memiliki jiwa entrepreneurship, menjadi lulusan yang berorientasi pencipta kerja bukan pencari kerja. (8) Bekerjasama dengan perusahaan untuk mematangkan kemampuan dan ketrampilan entrepreneurship para mahasiswa. Tujuan dari kerjasama ini untuk memudahkan para mahasiswa untuk beradaptasi dan berkarya secara nyata dalam suatu kondisi. Tentunya perusahaan yang sesuai dengan materi dan jurusan para mahasiswa. Sehingga, para mahasiswa bisa lebih mudah dan semangat juga mengerti pembelajaran entrepreneurship dan prospek perusahaan yang dimaksud. (9) Bersinergi dengan pemerintah, karena mereka adalah pihak yang bertanggung jawab terhadap masa depan rakyatnya. Segala upaya harus dilakukan untuk memajukan bangsa. Pemerintah harus berkompeten memberikan pendidikan entrepreneurship pada genesari masa depan bangsa agar kedepan mereka tampil sebagai sosok yang mandiri, lokomotif perubahan ke arah yang lebih baik, dinamis, progresif dan kompetitif. Kesejahteraan menjadi indikator utama kemajuan sebuah bangsa.

Seperti yang telah dipaparkan di atas, maka sejalan dengan pemikiran salah satu pengusaha seperti Bob Sadino bahwa institut pendidikan semestinya memperbaiki dan merubah pandangan dan cara pendidikan yang telah dilaksanakan sekarang. Ada teori dan ada praktek dilapangan, itulah mengapa Bob Sadino dalam Sadino \& Mawardi (2007) sering mengeluarkan pepatah "Kalau mau kaya, ngapain sekolah". Seiring dengan banyak pihak yang menentangnya, beliau memberikan penjelasan yang berkaitan juga dengan pentingnya pendidikan entrepreneur kepada mahasiswa dengan menggunakan diagram seperti pada Gambar 1. 


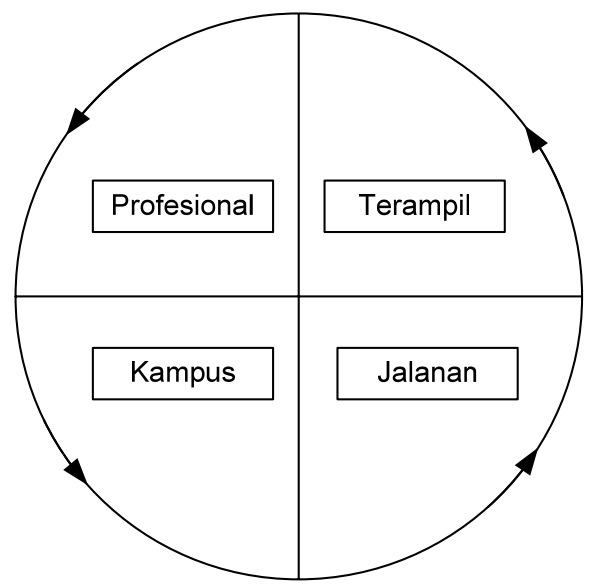

Gambar 1 Roda Bob Sadino (RBS)

Sumber: Belajar Goblok Dari Bob Sadino (2007)

Gambar 1 menjelaskan bahwa seorang entrepreneur juga memerlukan waktu untuk kembali ke sekolah atau kampus untuk mempelajari apa yang individu tersebut tidak ketahui menjadi tahu atau mendapatkan pengetahuan yang dibutuhkan. Pengetahuan apa ? Pengetahuan yang berguna untuk dipraktekkan di lapangan atau di jalanan. Memanfaatkan pengetahuan yang diperlukan dalam menjalankan usaha dijalaninya, detil-detil yang terkait didalamnya. Setelah mempraktekkan pengetahuan yang diperoleh dari kampus atau sekolah maka setelah beberapa lama, individu tersebut akan menjadi individu yang terampil. Pandai dalam melakukan apa yang didasarkan dari pengetahuan dalam menjalankan jenis usahanya. Dengan menjadi terampil maka individu tersebut menjadi professional. Ahli dalam bidang sebuah usaha tersebut. Semua orang akan menanyakan kepada sang pakar perihal pengetahuan atau ilmu yang berhubungan dengan usaha tersebut. Akan tetapi tidak semua pertanyaan bisa dijawab yang sudah menjadi professional. Kalau begitu bagaimana caranya untuk menjawab pertanyaan tersebut ? Dengan kembali lagi ke kampus atau mencari lagi ilmu yang baru dan berkembang dari tahun ke tahun. Dan tidak berhenti disitu saja, kegiatan itu akan berulangulang terus menerus tanpa berhenti baik dalam perkembangan ilmu di kampus atau sekolah dan kondisi di lapangan. Sayangnya yang terjadi adalah individu tersebut berhenti bergerak pada roda di dalam kampus atau sekolah, oleh karena merasa dirinya pintar dan tidak mau tahu praktik di lapangan. Berbeda dengan individu yang melakukan praktek langsung di lapangan, mau tidak mau harus memahami bahasa akadenik, bahasa kampus atau teori yang sesuai dengan bidangnya. Walaupun sudah terampil di satu bidang, individu yang sudah melakukan prakteknya, tetap harus mencari tahu berbagai teori dari banyak sumber. Karena kalau tidak tahu kemampuannya mungkin tidak akan maksimal.

Untuk mempersiapkan mahasiswa menjadi calon entrepreneur terdapat dua hal yang menjadi faktor kunci menurut Asmani (2011), yaitu: (1) metode pembelajaran yang akan disampaikan ke mahasiswa adalah berbasiskan pengalaman atau yang disebut experimental learning. Metode ini para mahasiswa dibawa ke dalam situasi khusus dimana mereka akan sekaligus memahami konsep, melatih keterampilan, dan membentuk sikap serta semangat seorang entrepreneur; (2) metode dan lingkungan belajar yang melibatkan mentor atau yang disebut mentor based learning. Metode ini melibatkan mentor yang merupakan entrepreneur aktif dimana dapat mempengaruhi mahasiswa dengan memberikan semangat dan pola piker entrepreneur kepada para mahasiswa.

Sehingga kita harus menanamkan kesesungguhan dalam melakukannya, baik mendalami usaha yang akan dibuka dan dijalaninya dengan kesungguhan. Mencari tahu seluruh hal yang terkait dalam usaha tersebut, melihat langsung di lapangan untuk bidang usaha tersebut seperti dalam bentuk trendnya, berapa lama trend tersebut akan berjalan, kapan waktu yang terbaik untuk 
memanfaatkannya, apa yang lagi tren untuk usaha tersebut, bagaimana permintaan dari konsumennya, dan bagaimana cara memenuhinya. Jangan terlalu memikirkan detil yang terlalu dalam, diutamakan mencari hal-hal utama terlebih dahulu. Contohnya, apabila mau membuka usaha restoran, jangan pikirkan terlebih dahulu bentuk tempat dari restoran tersebut. Akan tetapi memikirkan terlebih dahulu makanan atau minuman apa yang ingin anda perjual belikan. Memilah-milah makanan dan minuman mana saja yang cocok dengan usaha anda tanpa harus terlalu berlebih-lebihan dan terlalu banyak. Supaya anda tidak akan kesusahan dalam mencarinya. Baru dari situ mulai membuat detil tentang makanan, minuman dan lokasi yang strategis tempat restoran itu didirikan. Sehingga dari berbagai jenis makanan dan minuman yang sebelumnya anda idekan akan terlihat yang mana saja cocok dengan usaha anda, lalu buang ide makanan dan minuman yang tidak cocok dengannya. Setelah itu, baru berikutnya membuat konsep tempat restoran yang diinginkan berdasarkan pada jenis makanan dan minumannya. Dengan kita melakukannya dengan sunggu-sungguh maka terbentuklah gambaran usaha yang diinginkan oleh kita sendiri.

Sesudah kita melakukannya, selanjutnya kita harus dengan bersungguh-sungguh mencari halhal yang sudah didapat dalam gambaran atau draft dan dibuat menjadi kenyataan. Jangan hanya berandai-andai tetapi juga langsung melakukannya. Mulai tenaga kerja seperti contoh diatas koki yang khusus dengan mempunyai jam terbang banyak untuk memasak dan meracik bahan-bahan tersedia menjadi makanan atau minuman sesuai dengan konsep restoran sendiri. Atau apabila anda sendiri yang menjalankannya sebagai koki di restoran sendiri, mulai mencari bahan-bahan makanan dan minuman yang dibutuhkan. Membuatnya tidak hanya sesuai dengan selera diri sendiri akan tetapi juga selera umumnya. Karena selera setiap orang berbeda-beda satu sama lain. Dalam waktu bersamaan tidak hanya meracik makanan dan minumannya, juga mulai membuat dan menata tata letak interior tempat restoran tersebut yang disesuaikan dengan selera umumnya. Desain tata letak dan interior yang cocok dengan situasi dan kondisi sebuah restoran diinginkan.

Setelah itu kita menjalaninya tetap dengan kesungguhan dalam segala macam hal yang bersangkut paut di dalam sebuah usaha. Semua unsur-unsur yang terkait didalamnya harus dijalankan dengan kesungguhan karena akan dapat membawa usaha kita menjadi berjalan dengan baik dan tepat di jalurnya. Maka dari itu kesungguhan harus tertanam dari awal sampai akhir perjalanan dalam merintis sebuah usaha yang diinginkan. Maka dari itu perlu adanya pendidikan mengenai entrepreneur bagi para sarjana sehingga disatu sisi mempersiapkan mereka setelah mendapatkan gelar sarjana dan lulus juga mempersiapkan meeka apabila tidak mendapatkan pekerjaan dan memilih jalan menjadi entrepreneur.

\section{PENUTUP}

Melihat teori-teori yang telah dipaparkan diatas maka bisa dipastikan bahwa metode pembelajaran entrepreneur akan berubah atau diperbaiki setiap saat dengan perkembangan baik dari pendidikan juga dari lapangan. Maka dari itu bisa disimpulkan bahwa belum ada baik materi maupun bahan pengajaran untuk memperkenalkan entrepreneur kepada mahasiswa secara baku. Dengan melihat tidak saja dari teori-teori yang berkaitan dengan dan juga praktek di lapangan yang sangat membantu dalam membuat materi dan cara pengajaran di institut pendidikan. Sehingga masingmasing institut pendidikan mempunyai cara pendekatan sendiri-sendiri dalam melakukan pengajaran tersebut. Institut pendidikan mempunyai peran dalam memberikan pengajaran kepada para mahasiswa tidak hanya ilmu yang didapatkan berdasarkan jurusan dimana mereka mengikutinya, akan tetapi juga memberikan persiapan setelah mereka lulus dan tidak mendapatkan pekerjaan yang diinginkan, mempunyai alternatif dalam menjalankan sumbangsih kepada masyarakat. Tidak menjadi beban bagi keluarga dan masyarakat sekitarnya. Pendidikan entrepreneurship yang hendaknya diberikan kepada para mahasiswa tidak hanya berupa teori yang berkaitan satu sama lain akan tetapi juga adanya 
praktek langsung dilapangan baik kerjasama dengan perusahaan Perusahaan yang terlibat harus menyediakan tempat bagi para mahasiswa untuk mempraktekkan apa yang didapat selama perkuliahan dan juga mengasah jiwa entrepreneurshipnya. Pemerintah juga mempunyai peran aktif untuk membantu mahasiswa, institut pendidikan dan perusahaan dalam penyelenggaraan tersebut. Memberikan fasilitas dan sarana yang memadai sehingga pelaksanaan pendidikan dapat berjalan lancar tanpa ada gangguan dan ditunggangi kepentingan tertentu.

\section{Rekomendasi}

Semua pihak harus terlibat dan memberikan sumbangsih tidak hanya dalam bentuk pengajaran teori akan tetapi juga praktiknya secara nyata di lingkungan baik perusahaan kecil, menengah dan besar, institut pendidikan yang menyelenggarakan pendidikan juga pemerintah. Insitiut pendidikan dalam kerjasamanya mengembangkan mata kuliah dan pengajaran entrepreneurship harus melibatkan semua pihak. Dengan tujuan agar mata kuliah yang dihasilkan bisa langsung digunakan bagi para mahasiswa untuk dipakai di lapangan tanpa ada kendala. Instititut pendidikan, perusahaan skala kecil, menengah dan besar begitu juga pemerintah harus memberikan sarana dan fasilitas yang akan membantu pengajaran bagi mahasiswa.

\section{DAFTAR PUSTAKA}

Al-Firdaus, I. (2010). Cara gila untuk kaya Bob Sadino dan Purdi E. Chandra (mau sukses bisnis itu ya harus gila). Jogjakarta: BukuBiru.

Asmani, J. M. (2011). Sekolah entrepreneur: mendesain, menerapkan, dan memproduk insan-insan edukatif bermental pencipta kerja, bukan pencari lapangan kerja. Jakarta: Buku Kita.

Bandura, A. (1986). Social foundations of thought and action. Englewood Cliffs, NJ: Prentice Hall.

Kuratko, D. F. (2009). Introduction to entrepreneurship. Canada: South-Western Cengage Learning.

Lupiyoadi, R. (2004). Entrepreneurship from mindset to strategy. Jakarta: Penerbitan Fakultas Ekonomi Universitas Indonesia.

Sadino, B., \& Mawardi, D. (2007). Belajar goblok dari Bob Sadino. Jakarta: Kintamani. 